\title{
The diet of Antarctic fur seals Arctocephalus gazella (Peters) during the breeding season at Heard Island
}

\author{
K. GREEN, H.R. BURTON and R. WILLIAMS \\ Antarctic Division, Channel Highway, Kingston, Tasmania 7050, Australia
}

\begin{abstract}
Between September 1987 and February 1988, Antarctic fur seals Arctocephalus gazella (Peters) at Heard Island fed mainly on fish with an average $95.2 \%$ of scats in monthly collections containing fish remains. Pelagic myctophids constituted more than $50 \%$ of fish taken by fur seals at the beginning of the summer season and again at the end when there was an influx of non-breeding male seals. During the middle period from October to December, fish from the surrounding shelf area comprised the bulk of the diet. These included various benthic nototheniid species, the bentho-pelagic ice fish Champsocephalus gunnari Lönnberg and skate (Bathyraja spp.), the latter being found in over $60 \%$ of scats in October and November. The population of Antarctic fur seals at Heard Island is increasing at about the same rate as at South Georgia. There the increase is thought to be due to the high availability of krill $E$. superba, but in the present study no euphausiid remains were found, so the increasing population at Heard Island has been supported on a diet of fish. Whether this population increase can be sustained in future on a diet of fish is arguable. Trial fishing around Heard Island indicates that one of the major dietary items of the seals $(C$. gunnari) is of probable commercial importance and therefore any plans for the establishment of a fishery on Heard Island grounds must be considered in this light.
\end{abstract}

Received 31 May 1989, accepted 24 July 1989

Key words: Bathyraja, Champsocephalus, Notothenidae, Subantarctic

\section{Introduction}

Antarctic fur seals (Arctocephalus gazella) breed mainly on islands south of the Antarctic Convergence, on the South Orkney and South Shetland Islands, South Georgia, South Sandwich Islands, Bouvetøya, Iles Kerguelen, Heard and MacDonald Islands, with only three colonies (on Marion Island, Iles Crozet and Macquarie Island) lying north of the Convergence (King 1983, Jouventin et al. 1982, Shaughnessy $\&$ Fletcher 1987). There are few data on the diet of Antarctic fur seals, and the little information available comes from South Georgia where populations feed mainly on krill (Euphausia superba Dana) (Bonner 1968, North et al. 1983).

Heard Island is located at $53^{\circ} 05^{\prime} \mathrm{S}, 73^{\circ} 30^{\prime} \mathrm{E}$, approximately $360 \mathrm{~km}$ south-east of Iles Kerguelen and south of the Antarctic Convergence. Although there are early (presealing) records of fur seals breeding on Iles Kerguelen, there are no records of them breeding on Heard Island prior to 1963 (Budd \& Downes 1969). Although there exists a record, reported in Roberts (1950), which suggests that 500 fur seals were killed by the Yankee sealer Captain E.D. Roger, Rogers' own detailed journal makes no mention of this (Richards 1981). The existence of this earlier population is the subject of some speculation as it could suggest earlier unreported sealing (Shaughnessy et al. 1988). Such unrecorded visits are, however, considered extremely doubtful (Richards 1981). Roberts (1950) for example, recorded five sightings by ships in the two years prior to the landing by Captain Rogers, none of which landed a party on the island. As all the sealing vessels were based on nearby Iles Kerguelen and made return voyages from Heard Island, the report of fur seal skins from the cargo landed at any commercial port is only evidence of their capture at either island group.

Following the report of two pups born on Heard Island in 1963 (Budd \& Downes 1969), few visits were made to the island and only three pups were reported in 1969 and 1971 (Budd 1970, 1972). By the next report (Johnstone 1982) the number of pups had risen to about 46 and increased rapidly thereafter to 172 by $1986 / 87$ (Shaughnessy et al. 1988) and 248 by $1987 / 88$ (P.D. Shaughnessy \& S.D. Goldsworthy, personal communication 1989). The continued exponential increase at South Georgia is attributed to the high populations of krill $E$. superba upon which the fur seals feed (Bonner 1968, Doidge \& Croxall 1985), and in years of low krill availability the pup survival is reduced (Croxall $e t$ al. 1988). E. superba does not occur around Heard Island where it is replaced by much smaller and less abundant species such as Euphausia vallentini Stebbing.

The present study was aimed at examining the diet of a small but rapidly increasing population of Antarctic fur seals in an area where krill is not abundant.

\section{Methods}

Fur seal faeces were collected at Red Island peninsula and at 
Spit Bay at opposite ends of Heard Island from early October 1987 to late February 1988 (Fig. 1).

Pupping peaked in mid-December and was followed by an influx of non-breeding males which lead to peak numbers at Red Island in early January. At Spit Bay the last census was conducted in mid-February, when the numbers of nonbreeding males had shown no sign of reaching a peak (P.D. Shaughnessy \& S.D. Goldsworthy, personal communication 1989).

After snow melt in early October, fur seal faeces were removed from all the sites and were cleared thereafter by the end of each month. In addition, some fresh faecal material was collected opportunistically. There was no collection in January at Red Island due to difficulties with access. Data for each month were plotted for the middle of that month and when data were combined for January and February they were plotted for the end of January. Individual faecal samples were kept separate and were returned to the laboratory for analysis cither dried, or preserved in $70 \%$ ethanol. Faecal samples were broken open in water in a sieve of
$1.0 \mathrm{~mm}$ mesh. Fish otoliths were extracted in an orangecoloured tray and the residue was sorted beneath a dissecting microscope. Fish otoliths, vertebrae, teeth, dermal denticles and thorns, polychaete mouthparts, crustacean remains and cephalopod beaks were removed for further identification and measurement.

Most fish remains were assigned specific identities on the basis of otoliths. In the absence of remains sufficient for specific identification, bony fish remains were classified for estimation of frequency of occurrence into pelagic types (myctophids), benthic types (nototheniids and Channichthys rhinoceratus) and the bentho-pelagic Champsocephalus gunnari according to the characteristics of the vertebrae (degree of ribbing, the length-width ratio and the diameter of the lumen) compared with reference skeletons of known species. The presence of skates was determined by the presence of teeth, dermal denticles and thoms.

There was no significant difference found using paired $t-$ tests between the occurrence of major fish types in samples from either end of Heard Island so data for all samples for a

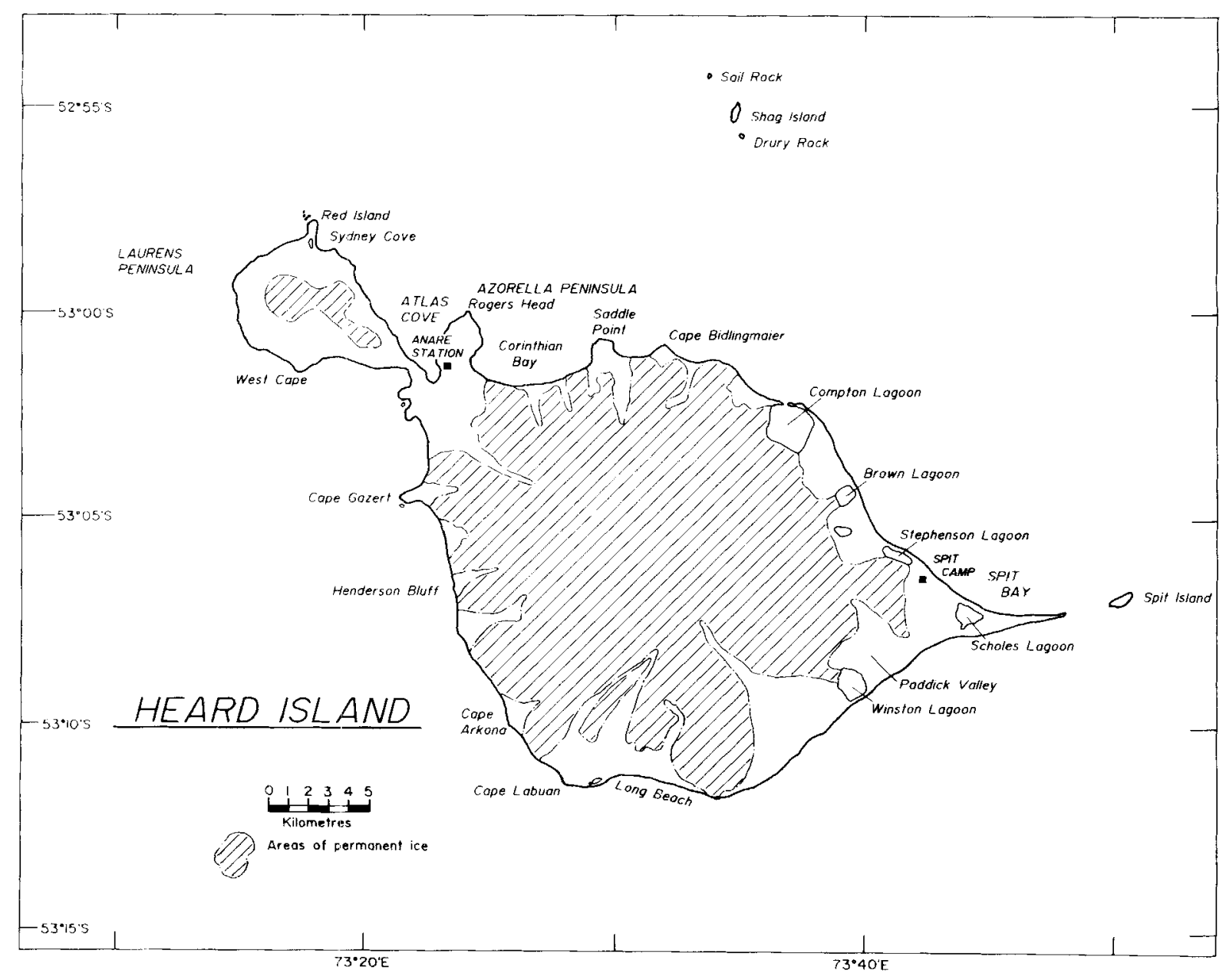

Fig. 1. Heard Island. Faecal collections were made at the north-west tip at Red Island and on the north-east coast in Spit Bay at two sites near Spit Camp. 
particular month were pooled for further analysis.

Standard lengths of fish prey were estimated from measurements of either the length or width of otoliths, whichever provided the best regression of otolith size to fish size for reference specimens. Only otoliths showing very little or no signs of erosion were used for this purpose. Formulae derived from fish of known size were used to calculate standard lengths from the otolith measurements.

\section{Results}

A total of 563 faecal samples was collected. Similar numbers came from each end of Heard Island, although there were differences in the numbers collected each month (Table I). The collection of faecal material for September probably contained some material from earlier in the year as sites could not be cleared of faeces before this collection. However, examination of scats over the ensuing five months indicated that these were unlikely to be identifiable after approximately one month due to decomposition by fly larvae, disturbance by animal traffic, and the action of rain and wind. Thus, most of the September material would have been deposited in September and August. Because there was no collection in January at Red Island, results for January and February were pooled. Of the 563 faecal samples, 63 passed through the sieve leaving no remains and were therefore not used in further analysis. The majority of 'empty' samples were collected in February and may have been from moulting animals that were fasting at this time (Table I).

Fish remains predominated in fur seal faeces, occurring in an average of $95.2 \%$ of droppings in any collection period (Table II). Bony fish occurred in an average $91.5 \%$ of droppings, and skate (Rajidae) in 51.5\% (Table II). Seventeen species of bony fish were identified from otoliths (Table III). There are three species of skate occurring in waters around Heard Island, Bathyraja eatonii (Gunther), B. murrayi (Gunther) and B. irrasa Hureau \& Ozouf-Costaz. The skate denticles could not, however, be separated on the basis of

Table I. Temporal and spatial distribution of fur seal faecal samples at Heard Island, numbers in parentheses are additional scats (not used in analysis of frequency of occurrence) which left no remains in sieves.

\begin{tabular}{lrrr}
\hline Location & $\begin{array}{c}\text { Red Island } \\
\mathbf{n}\end{array}$ & \multicolumn{2}{c}{$\begin{array}{c}\text { Spit Bay } \\
\mathbf{n}\end{array}$} \\
\hline September & $71(4)$ & $35(3)$ \\
October & 54 & $(1)$ & $55(1)$ \\
November & $60(7)$ & $32(0)$ \\
December & $34(3)$ & $15(0)$ \\
January & & & $87(2)$ \\
February & $24(26)$ & $33(16)$ \\
Total (excluding 'empty' scats) & 243 & 257 \\
Total (including 'empty' scats) & 284 & 279 \\
\hline
\end{tabular}

Table II. Percentage frequency of occurrence of remains in faeces of Antarctic fur seals at Heard Island. Jan/Feb includes material collected at both ends of Heard Island, data for these two months are presented separately for Spit Bay (in parentheses).

\begin{tabular}{lccccccccc}
\hline Item & Sept & Oct & Nov & Dec & Jan/Feb & Mean & (Jan) & (Feb) \\
\cline { 5 - 8 } All fish & 93.4 & 99.1 & 98.9 & 93.9 & 90.6 & 95.2 & $(93.1)$ & $(93.9)$ \\
Skate & 57.5 & 71.6 & 62.0 & 30.6 & 36.2 & 51.6 & $(43.7)$ & $(33.3)$ \\
Bony fish & 86.8 & 97.2 & 95.7 & 91.8 & 85.9 & 91.5 & $(90.8)$ & $(84.8)$ \\
Pelagic & 20.8 & 15.6 & 13.0 & 28.6 & 33.6 & 22.3 & $(27.6)$ & $(54.4)$ \\
C. gunnari & 14.2 & 6.4 & 9.8 & 12.2 & 26.8 & 13.9 & $(34.5)$ & $(15.2)$ \\
Benthic fish & 32.1 & 24.8 & 18.5 & 22.4 & 14.8 & 22.5 & $(21.8)$ & $(0)$ \\
Fish eggs & 0.9 & 3.7 & 1.1 & 0 & 0.7 & 1.3 & $(1.1)$ & $(0)$ \\
Squid & 2.8 & 3.7 & 1.1 & 2.0 & 7.4 & 3.4 & $(5.7)$ & $(15.2)$ \\
Octopus & 0 & 0.9 & 0 & 0 & 0 & 0.2 & $(0)$ & $(0)$ \\
Mollusc shell & 4.7 & 0 & 0 & 0 & 0 & 0.9 & $(0)$ & $(0)$ \\
Amphipod & 3.8 & 0.9 & 0 & 0 & 1.4 & 0.9 & $(0)$ & $(6.1)$ \\
Isopod & 0.9 & 0 & 0 & 0 & 0 & 0.2 & $(0)$ & $(0)$ \\
Indet. crustacean & 7.5 & 0.9 & 0 & 2.0 & 2.0 & 2.5 & $(1.1)$ & $(3.0)$ \\
Polychaete & 4.7 & 7.4 & 4.3 & 6.1 & 2.7 & 5.0 & $(4.6)$ & $(0)$ \\
Bryozoan/ & & & & & & & & \\
Hydrozoan & 0.9 & 0 & 0 & 0 & 1.3 & 0.4 & $(0)$ & $(0)$ \\
Mammal & 1.9 & 1.9 & 0 & 0 & 0 & 0.8 & $(0)$ & $(0)$ \\
Penguin & 4.7 & 2.8 & 0 & 14.3 & 2.0 & 4.8 & $(4.6)$ & $(0)$ \\
Neamatode/ & & & & & & & & \\
Cestode & 10.4 & 0 & 0 & 0 & 2.0 & 2.5 & $(3.4)$ & $(0)$ \\
Unidentified & 3.8 & 1.9 & 1.1 & 0 & 2.7 & 1.9 & $(1.1)$ & $(0)$ \\
& & & & & & & & \\
Total scats & 106 & 109 & 92 & 49 & 144 & 500 & $(87)$ & $(33)$ \\
\hline & & & & & & & & &
\end{tabular}

any species-specific differences and were therefore classed as Bathyraja spp., although the high number of thorns present in the scats suggests that $B$. murrayi was the main contributor as the other species have relatively few thorns. Otoliths from pelagic fish (myctophids) constituted over $50 \%$ of all otoliths in September and from December to February (Fig. 2). Otoliths from benthic fish (nototheniids and Channichthys rhinoceratus) were most common between September and November with few being found from December to February, and otoliths from the bentho-pelagic C. gunnari were most common in November (Fig. 2). The frequency of occurrence of skate remains reflected the pattern of predation on the bony fishes, occurring with a high frequency when otoliths of benthic bony fishes constituted a high proportion of all otoliths (Fig. 2). There was a significant negative correlation $(r=0.9, p<0.05)$ between the occurrence of the most pelagic of the fish (myctophids) and the most benthic (skate).

Antarctic fur seals fed predominantly on one size class of C. gunnari (Fig. 3). The mode of calculated standard length progressed slightly between months, indicating the growth of the size class preyed upon. There was also an increase in calculated standard length with time for Gymnoscopelus nicholsi but over a shorter time period, as sufficient otoliths were available only for December and January-February (Fig. 3). Predation on Electrona antarctica was common only in September and October and a clear peak in distribution 


\begin{tabular}{|c|c|c|c|c|c|}
\hline Species & Sept & Oct & Nov & Dec & $\mathrm{Jan} / \mathrm{Feb}$ \\
\hline Krefftichthys anderssoni (Lönnberg) & 0.4 & $\mathbf{0}$ & 1.7 & 0.5 & 0.9 \\
\hline Protomyctophum bolini (Fraser-Brunner) & 0.4 & 0 & 0 & 1.0 & 0 \\
\hline Electrona antarctica (Gunther) & 42.4 & 8.4 & 0 & 1.0 & 6.3 \\
\hline E. subaspera (Gunther) & 3.5 & 10.9 & 0 & 1.9 & 2.6 \\
\hline E. carlsbergi (Taning) & 2.0 & 0 & 9.3 & 3.4 & 7.7 \\
\hline Gymnoscopelus bolini Andriashev & 0 & 0 & 0 & 0 & 6.4 \\
\hline G. braueri (Lönnberg) & 0 & 0 & 0 & 1.0 & 5.3 \\
\hline G. nicholsi (Gilbert) & 2.3 & 2.5 & 0.9 & 52.9 & 33.5 \\
\hline indet myctophid & 0 & 0.8 & 0 & 0 & 5.9 \\
\hline Pelagic (sub total) & 51.0 & 22.6 & 11.9 & 61.7 & 68.6 \\
\hline Dissostichus eleginoides Smitt & 0.8 & 0 & 0 & 0 & 0 \\
\hline Notothenia rossii Richardson & 3.5 & 0 & 0.9 & 1.0 & 0 \\
\hline N. coriiceps Richardson & 7.0 & 0 & 0 & 0 & 0 \\
\hline N. sqamifrons Gunther & 8.2 & 22.7 & 16.1 & 0 & 0.2 \\
\hline N. acuta Gunther & 0.8 & 3.4 & 4.2 & 3.4 & 0 \\
\hline Nolotheniops mizops (Gunther) & 0.8 & 3.4 & 0.9 & 0 & 0 \\
\hline indet nototheniid & 0.8 & 0.8 & 0 & 0.5 & 0 \\
\hline Channichthys rhinoceratus Richardson & 6.6 & 21.9 & 9.3 & 3.9 & 2.8 \\
\hline indet channichthyid & 0.4 & 0 & 1.7 & 1.0 & 0.1 \\
\hline Zanclorhynchus spinifer Gunther & 0 & 0 & 0 & 0 & 0.2 \\
\hline Benthic (sub total) & 28.9 & 52.2 & 33.1 & 9.8 & 3.3 \\
\hline Champsocephalus gunnari Lönnberg & 10.5 & 19.3 & 50.9 & 27.9 & 25.7 \\
\hline Unidentified & 9.7 & 5.9 & 4.2 & 1.0 & 2.4 \\
\hline Number of otoliths & 257 & 119 & 118 & 208 & 1407 \\
\hline
\end{tabular}

Table III. Species of fishes identified from otoliths in faeces of Antarctic fur seals from Heard Island as a percentage of the number of otoliths for five time periods.

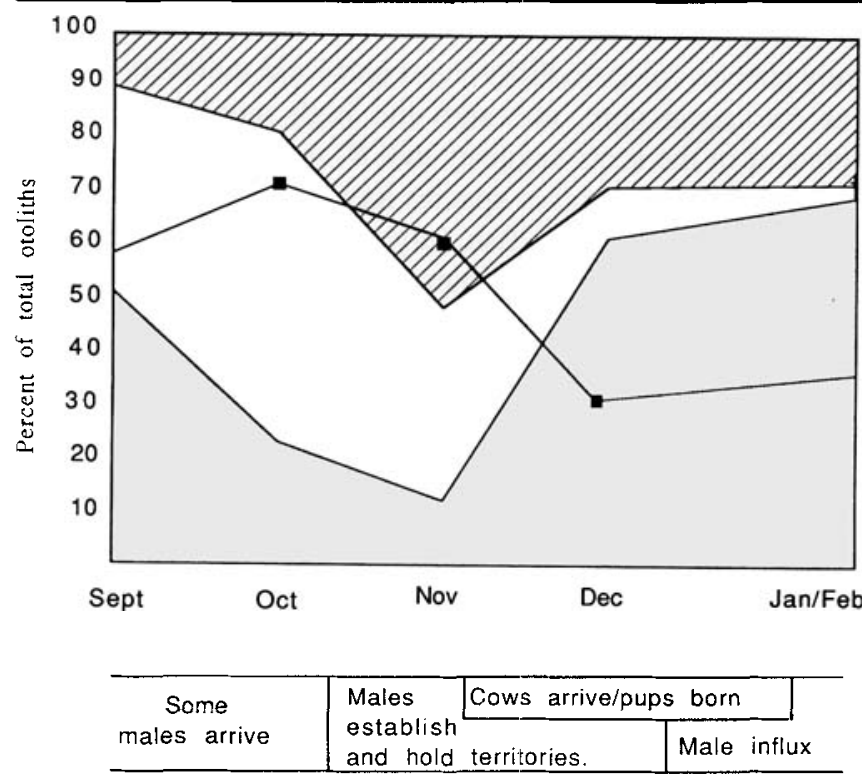

Fig. 2. The percentage composition of all otoliths by three broad groupings from Antarctic fur seal scats at Heard Island: Champsocephalus gunnari ( $\mathrm{Q})$, benthic species of Nototheniidae and Channichthyidae $(\square)$ and pelagic myctophids (shaded). (Data from Table III.) Superimposed is the percentage frequency of occurrence of skate in faecal material ( - - $)$. of sizes is noticeable at that time but not later in the season when few $E$. antarctica were taken (Fig. 3). There were no clear peaks in the calculated standard length of the benthic C. rhinoceratus taken (Fig. 3).

\section{Discussion}

\section{Methods}

A major assumption of most studies of faecal samples is that there is no selective oral ejection of hard parts. This is not the case in some species, and the Cape fur seal $A$. pusillus (Schreber) and New Zealand fur seal A. forsteri (Lesson), both of which commonly feed on squid, do eject squid beaks orally (Rand 1959, Tate 1981). However, this type of regurgitation has not been reported in the literature for $A$. gazella and, over many hours of observation, has not been observed at South Georgia (J.P. Croxall, personal communication 1989), the South Shetland Islands (L. Ferm, personal communication 1989), Heard Island (S.D. Goldsworthy, personal communication 1989) or Macquarie Island (P.D. Shaughnessy, S.D. Goldsworthy, K. Handasyde, personal communication 1989). It would appear, therefore, that there is no evidence for selective ejection of squid beaks in $A$. gazella and thus faecal material will not be biased against sampling squid in the diet.

A number of studies have investigated the reliability of 

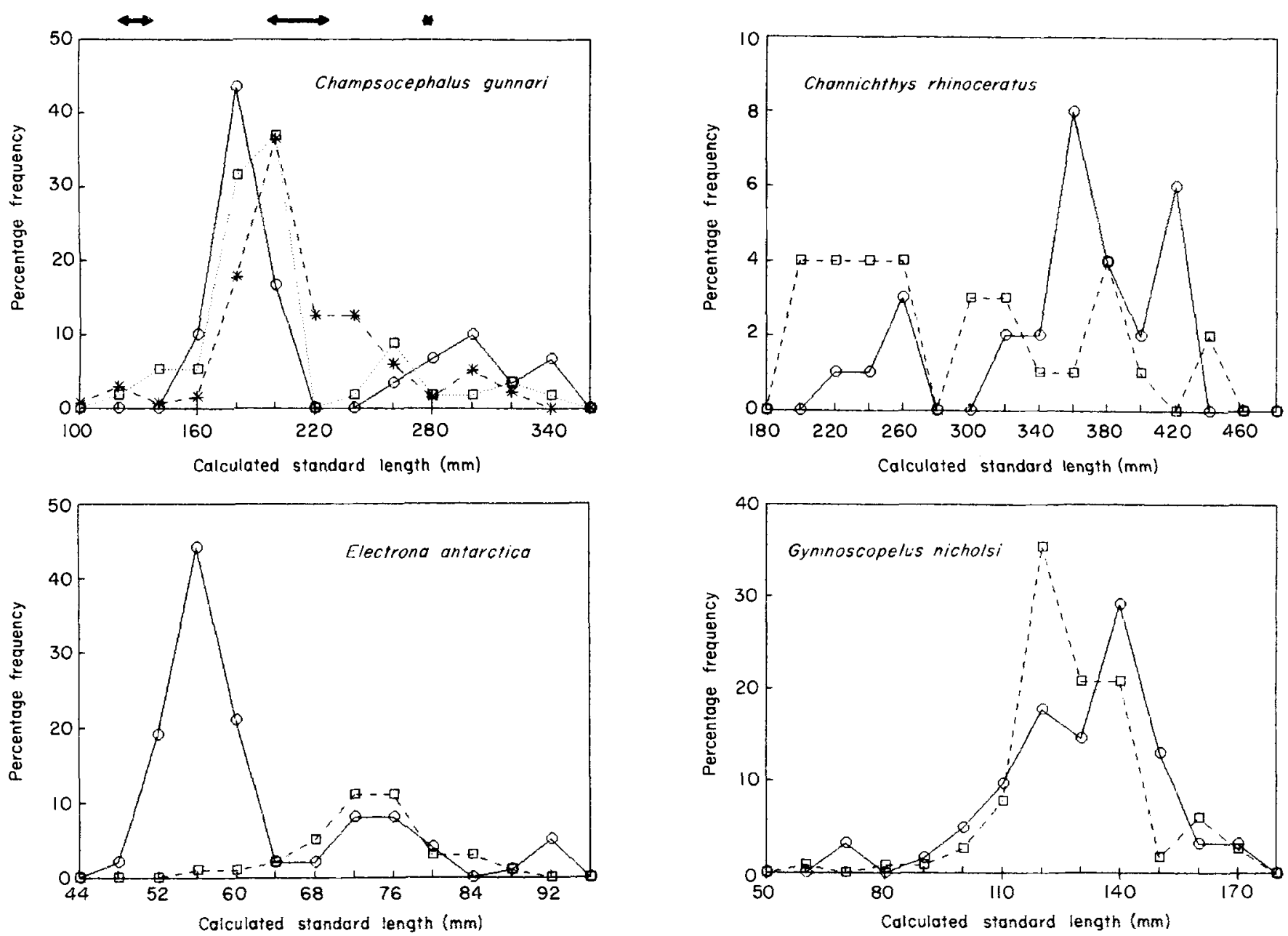

Fig. 3. The frequency of calculated standard lengths of Champsocephalus gunnari (Sept/Oct $-\odot-$ Nov/Dec ..๑.. Jan/Feb -**-) Channichthys rhinoceratus (Sept--Nov - - - Dec-Feb -- - --), Electrona antarctica (Sept-Nov $-\rightarrow-$ Dec-Feb -- - -) and Gymnoscopelus nicholsi (Dec - - Jan $\backslash F e b--\theta_{--}$) taken by Antarctic fur seals. For C. gunnari the length ranges between September and February of one-year-old $(\hookrightarrow)$, two-year-old $(\longleftrightarrow$ ) and three-year-old fish $(\bullet)$ (taken from Duhamel 1987) are indicated.

scat analysis, especially where it concerns deriving information from otoliths (Jobling \& Breiby 1986, Dellinger \& Trillmich 1988). The main concerns with the use of otoliths are that the dimensions may be reduced by digestion and that otoliths of different sizes or from different species may be digested at different rates, thus biasing the results.

Dellinger \& Trillmich (1988) stated that, in their study, fish lengths would have been underestimated by $15 \%$ and suggested that other published results would be likely to yield underestimates based on extrapolation from otolith size. However, they failed to acknowledge that in most studies of the diet of wild seals, otoliths are classified on the basis of their level of digestion and significantly eroded specimens are removed from the analysis for the estimation of size. Thus Green \& Burton (1987), working with Weddell seals, found that otoliths taken from faeces were only $3.3 \%$ smaller than otoliths from the same fish species taken from undigested fish in seal stomachs. In the present study, the calculated sizes of $C$. gunnari based on otoliths taken from faeces are in reasonable accord with the length-frequency distribution expected from the data of Duhamel (1987) from the neighbouring Kerguelen area (Fig. 3), especially for the modal prey size. For this reason (predation mainly on one size class) differential digestion of different sizes of fish also does not appear to be a problem in the present study.

Dellinger \& Trillmich (1988) concluded that the ratios of numbers of otoliths of different species found in faeces corresponded with the ratio of those species fed to the seals but that the variance was high. They suggested that large samples of scats are necessary to obtain a representative picture of the numerical composition of diet of wild seals. We believe that the 500 scats and 2100 otoliths examined in this study comprise a sufficiently large sample.

\section{Overall diet}

The diet of Antarctic fur seals at Heard Island comprised 
mainly fish, in contrast with the previous work from the South Atlantic sector where the diet was predominantly krill (Bonner 1968, North et al. 1983, Doïdge \& Croxall 1985). Traces of fish occurred in about $10 \%$ of stomachs from Bird Island in 1971 to 1973 (Payne unpublished, cited in Doidge \& Croxall 1985) and in "very few" in 1983 (Doidge \& Croxall 1985). On South Georgia itself, fish occurred in $1 \%$ of stomachs in 1982 (Doidge \& Croxall 1985) whereas the majority contained mainly krill. In the present study very little crustacean material occurred, and, except where amphipods constituted nearly all of the material in the scat, crustacean remains were very fragmented and were possibly taken originally by the ingested fish, the inshore species of which prey commonly on amphipods (Williams 1983).

Although fish were not quantified in the diet of fur seals at South Georgia, Bonner (1968) indicated their occurrence by differentiating between the more common pinkish-red faeces (containing krill remains) and the less common greyish faeces (containing fish) and concluded that the staple diet of the fur seals was krill. Although Bonner (1968) found that stomachs of breeding females contained only krill he suggested that non-breeding seals take 'appreciable quantities of fish, and quite possibly anything else of an edible nature that is available'. This opportunistic predation appears to be characteristic of breeding seals as well as non-breeders in the present study and is reflected in the variety of prey, including skates and polychaetes.

After December, scats likely to contain fish were activcly sought by North et al. (1983) at South Georgia and eight such scats were collected. Five of the eight scats were dominated by $C$. gunnari, and overall it was the most important fish species, the other fish species taken at South Georgia and also taken at Heard Island being G. nicholsi and Notothenia rossii. Other species taken at South Georgia were Notothenia gibberifrons Lönnberg, Pagothenia hansoni (Boulenger), Nototheniops larseni (Lönnberg) and Pseudochaenichthys georgianus Norman, which do not occur at Heard Island. Notothenia rossii is the most common nearshore fish species at South Georgia (Burchett 1983) but is virtually absent from the diet. North et al. (1983) suggested that this may be because of its benthic habit or because of a reduction in abundance of this species. Juveniles of $N$.rossi are one of the most common inshore fishes around Heard Island and yet it is uncommon in the diet there too. Notothenia coriiceps is also common in the inshore waters of Heard Island (Williams 1983) and yet it occurred in the diet of fur seals during only one month, and then infrequently. The present study suggests that benthic habit per se need not affect the rate of predation. A possible explanation is that juvenile $N$. rossii and $N$. coriiceps, being both strictly benthic fish inhabiting areas covered relatively densely by macrophytic algae, may not be very accessible to the seals.

Bonner (1968) suggested that the reduction in the postcanine dentition in the Antarctic fur seal may be accounted for by postulating specialization for a diet of krill. This is obviously not the case at Heard Island, where the Antarctic fur seal feeds most commonly on fish. North et al. (1983) suggested that fish species associated with krill swarms were taken opportunistically by Antarctic fur seals around South Georgia. The reverse of this situation (euphausiids being taken opportunistically when seals preyed on associated fish) does not occur around Heard Island where the euphausiids are less than half the length of $E$. superba and, although $C$. gunnari feed on these euphausiids, they are probably too small for seals.

\section{Seasonal changes in diet}

There was a much greater seasonal change in diet at Heard Island than at South Georgia where North et al. (1983) found mainly krill in 50 randomly collected scats per month from November 1982 to March 1983 . However, $50 \%$ of the scats of immature fur seals on South Georgia in early spring contained fish remains (based on colour) (Prince, cited in North et al. 1983). With the Heard Island seals, however, there is a marked seasonal pattern in the diet from roughly equal proportions of benthic and pelagic fish in September, to November, when the pelagic myctophids were essentially replaced by the bentho-pelagic $C$. gunnari. After November, the occurrence of skate and benthic nototheniids declined and, as the proportion of bentho-pelagic C. gunnari decreased, the pelagic myctophids increased. These changes probably reflect the changes in the population structure of the seals on the island. Males, including breeding bulls, arrived first from oceanic waters as evidenced by the high proportion of pelagic fish, especially E. antarctica in their diet. They fed closer to land throughout the remainder of September and in October and November leading to a peak in the proportion of $C$. gunnari in November. The breeding females began arriving in mid to late November but numbered only 248 . The predominant class of seals was non-breeding males, which reached a size of approximately 15000 animals by the end of February. The influx of these oceanic feeders (the non-breeding males) from late December was probably responsible for the return to dominance of the pelagic myctophids, although the major species was $G$. nicholsi, which does occur on the shelf.

There are quite obvious seasonal changes in the sizes of $C$. gunnari, E. antarctica and G. nicholsi taken by fur seals, whereas there is no clear seasonal trend with the less mobile benthic species $C$. rhinoceratus (Fig. 3). Changes in estimated size of C. gunnari are attributable to the expected growth of the fish over this time and are close to measurements extrapolated from total lengths presented for the Kerguelen region by Duhamel (1987). Electrona antarctica were preyed on heavily only in the first month, presumably at a location where they were in high numbers and consequently had a size structure which is reflected in the diet. Later in the season only occasional E. antarctica were taken and the 
sample size was possibly not large enough to ascertain a size structure.

Gymnoscopelus nicholsi were most commonly taken in the last three months and also showed a consistent size structure.

In an area of water $110 \mathrm{~km}$ from Heard Island and 210-250 $\mathrm{m}$ deep, 149 fur seals were sighted between 10 May and 26 June 1987 and a further 53 seals were sighted on 27 July (P.H. Ensor \& P.D. Shaughnessy, personal communication 1989). In this area, catches by the Soviet fisheries research vessel RV Professor Mesyatsev of $C$. gunnari were high, and other species of fish taken by fur seals in summer (Dissostichus eleginoides, Notothenia rossii, $N$. squamifrons, $N$. acuta, Channichthys rhinoceratus and Bathyraja spp.) were also caught (Williams \& Ensor 1988). This indicates that there is probably a substantial winter population of Antarctic fur seals in the waters around Heard Island and that this population feeds on fish. North et al. (1983) also suggested that in winter Antarctic fur seals may be more important predators of fish, particularly C. gunnari.

\section{Implications for population trends of seals}

From the first record of pups on Bird Island after the cessation of sealing (12 pups were sighted in 1926) the population of Antarctic fur seals grew to 5330 pups in 21 years (Bonner 1968). From the earliest accurate count in 1958 (Bonner 1968) to 1972 the annual increase in pups born was $16.8 \%$ (Payne 1977). At Prince Edward and Marion Islands $A$. gazella is presently increasing at $15-16 \%$ per annum (Kerley 1983) and at Heard Island is increasing by $21 \%$ which suggests that immigration of breeding females is contributing towards the increase (P.D. Shaughnessy \& S.D. Goldsworthy, personal communication 1989). The long period of rapid increase in the number of seals at South Georgia is thought to have been based on a summer diet of krill, whose high numbers are believed to be a result of the lowered numbers of baleen whales currently present in the area (Bonner 1968, Doidge \& Croxall 1985). The Antarctic fur seal population on Heard Island has followed a trend similar to that on Bird Island in the 25 years since two pups were recorded in 1963 (Budd \& Downes 1969). Whereas the present rate of increase is high and comparable to that recorded at Bird Island, the total number of fur seal pups is still low. A question for the future is how long the present rate of increase of population can be maintained for the fur seal population on an island where fish are the main prey? At the present rate of increase the number of pups born on Heard Island would reach about 15000 in 20 years. Marking of the breeding population, and the measurement of breeding success, will be necessary to estimate the proportions of the increase that are due to resident Heard Island females and immigrant females. Future monitoring, both of fur seal numbers and of their diet, at a frequency of three to five years will be necessary to follow adequately the interaction between population numbers and diet.

\section{Interaction with fisheries}

A commercial fishery has existed in the Kerguelen region from the early 1970 s and catches averaged about 20000 tonnes per year between 1979 and 1986 (Williams \& Ensor 1988). Since then, the catches have been $7886 \mathrm{t}$ in 1987 and $773 \mathrm{t}$ in 1988. Before 1978, the benthic species $N$. rossii and $N$. squamifrons were the mainstay of this fishery; but $C$. gunnari increased in importance after that to constitute the majority of the catch. There has been little commercial fishing around Heard Island and none since a 200 nautical mile Australian fishing zone (AFZ) was declared in 1979 (Williams \& Ensor 1988). It is not known whether $C$. gunnari from around the two islands are from different stocks. Catches by the Soviet research vessel RV Professor Mesyatsev of C. gunnari on banks to the north-east of Heard Island indicated concentrations of this species of commercial interest, but other species, including benthic fishes also occurring in the diet of the seals are not sufficiently abundant for commercial interest at this time (Williams \& Ensor 1988). Regulations including mesh size restriction limit the size of $C$. gunnari taken by trawlers around Kerguelen to fish longer than $280 \mathrm{~mm}$. As the bulk of the summer diet of seals consists of subadult $C$. gunnari less than $240 \mathrm{~mm}$ in length (Fig. 3) there would, at first consideration, appear to be little direct competition for fish in summer. This appears to be a similar situation to that in the South Atlantic sector, where Doidge \& Croxall (1985) suggested that competition between commercial fisheries and Antarctic fur seals may not be acute as trawlers took mainly adult $N$. rossii whereas the seals took mainly juveniles. However, it is obvious that considerable catches of any size class by either seals or a fishery will have future effects on all size classes.

There is evidence that sub-adult and adult $C$. gunnari near Heard Island occupy slightly different areas (R. Williams, unpublished). The RV Professor Mesyatsev found a zone $30-65 \mathrm{~km}$ north-east of the island near the shelf edge where shoals of juvenile $C$. gunnari $160-190 \mathrm{~mm}$ long were abundant in May-June 1987. This length coincides with the modal lengths of fish whose remains are found in seal faeces, and the area is close to that where many seals were sighted (P.H. Ensor \& P.D. Shaughnessy, personal communication 1989) at a similar distance to that at which female fur seals from South Georgia first feed on foraging trips (Kooyman et al. 1986). Until we know more concerning the winter diet of seals at Heard Island, when they are not restricted to foraging from the island base, it is not possible to assess the potential conflict between seals and fisheries within the Heard Island AFZ. As seals have been sighted in May-June near concentrations of $C$. gunnari consisting mainly of adults and some juveniles (R. Williams, unpublished), it is possible that 
larger size classes of fish could be important prey at this time. This lack of knowledge of the winter diet underlies the need for year-round research on the diet of seals to augment the summer sampling reported here.

Bester \& Roux (1986) have suggested that the apparently slow recovery of fur seal populations on Iles Kerguelen was due to the lack of nearby concen trations of krill and that local stocks of fish and squid were inadequate to hasten population growth past the establishment phase into the anticipated third phase (see Roux 1987) of faster population growth. The population growth on Heard Island is, however, proceeding into this third stage and it will be important to continue to monitor pup production and diet to see what changes, if any, occur in the diet and the population growth.

Fisheries research has been undertaken in the vicinity of Heard Island and it is possible that, in the near future, approaches may be made to fish commercially in the area. The continuing expansion of the fur seal population and the possible establishment of a new fishery, both taking the commercial C. gunnari, are likely to lead to competition. This conclusion would indicate that further information on the diet of the Antarctic fur seal from stomach contents and scats (including at least a data set over a full year) and on the distribution size classes of C. gunnari around Heard Island cre important objectives to be achieved before the impact of a fishery could be assessed adequately.

\section{Acknowledgements}

The authors thank ANARE expeditioners who helped collect seal faeces on Heard Island in 1987-88, Mr M. Stolp (Antarctic Division) who identified crustaceans. Dr P.D. Shaughnessy (CSIRO) and Mr S.D. Goldsworthy (Monash University) commented critically on the manuscript.

\section{References}

BESTER, M.N. \& Roux, J.P. 1986. The second survey of Antarctic fur seals Arctocephalus gazella on the Courbet Peninsula, Iles Kerguelen. South African Journal of Antarctic Research, 16, 33-37.

BONNER, W.N. 1968. The fur seal of South Georgia. British Antarctic Survey Scientific Reports, No. 56, 83 pp.

BuDd, G.M. 1970. Rapid population increase in the Keguelen fur seal, Arctocephalus tropicalis gazella, at Heard Island. Mammalia, 34, $410-414$

Bund, G.M. 1972. Breeding of the fur seal at McDonald Islands, and further population growth at Heard Island. Mammalia, 36, 423-427.

Budd, G.M. \& Downes, M.C. 1969. Population increase and breeding in the Kerguelen fur seal, Arctocephalus tropicalis gazella, at Heard Island. Mammalia, 33, 58-67.

BURCHETT, M.S. 1983. Abundance of the nearshore fish population at South Georgia (Antarctica) sampled by trammel net. British Antarctic Survey Bulletin, No. 61, 39-43.

Croxall, J.P., McCann, T.S., Prince, P.A. \& Rothery, P. 1988. Reproductive performance of seabirds and seals at South Georgia and Signy Island, South Orkney Islands, 1976-1987: Implications for
Southem Ocean monitoring studies. In SAHRHAGE, D., ed. Antarclic ocean and resource variability. Berlin: Springer-Verlag, 261-285.

DELLINGER, T. \& TRHLMICH, F. 1988. Estimating diet composition from scat analysis in otariid seals (Otariidae): is it reliable? Canadian Journal of Zoology, 66, 1865-1870.

Dordge, D.W. \& CroxaLL, J.P. 1985. Diet and energy budget of the Antarctic fur seal, Arctocephalus gazella, at South Georgia. In SIEGFRIED, W.R., ConDY, P.R., \& LAws, R.M., eds. Antarctic nutrient cycles and food webs. Berlin: Springer-Verlag, 543-550.

DuHAMEL, G. 1987. Ichtyofaume des Secteurs Indien Occidental et Atlantique Oriental de l'Ocean Austral: Biogeographie, Cycles Biologiques et Dynamique des Populations. Ph.D. thesis, Université Pierre et Marie Curie, 687 pp. [Unpublished.]

GREEN, K. \& BURTON, H.R. 1987. Seasonal and geographical variation in the food of Weddell seals, Leptonychotes weddellii in Antarctica. Australian Wildlife Research, 14, 475-489.

JoBl.rNG, M. \& BREIBY, A. 1986. The use and abuse of fish otoliths in studies of feeding habits of marine piscivores. Sarsia, 71, 265-274.

Johnstone, G.W. 1982. Zoology. In Veenstra, C. \& Manning, J., eds. Expedition to the Australian Territory of Heard and McDonald Islands 1980. Division of National Mapping, Technical Report, 31, 33-39.

Jouventin, P., STAHL, J.C. \& WeIMERSKIRCH, H. 1982. La recolonisation des Iles Crozet par les otaries (Arctocephalus tropicalis et A. gazella). Mammalia, 46, 505-514.

KERLEY, G.I.H. 1983. Relative population sizes and trends, and hybridization of fur seals Arctocephalus tropicalis and A. gazella at the Prince Edward Islands, Southern Ocean. South African Journal of Zoology, 18, 388-392.

KING, J.E. 1983. Seals of the world. London: British Museum (Natural History), $240 \mathrm{pp}$.

KoOYMan, G.L. DAvIS, R.W. \& CroxalL, J.P. 1986. Diving behaviour of Antarctic fur seals. In GentRy, R.L. \& Kooyman, G.L., eds. Fur seals. Maternal strategies on land and at sea. Princeton: Princeton University Press, 115-125.

North, A.W., Croxall, J.P. \& Doidge, D.W. 1983. Fish prey of the Antarctic fur seal Arctocephalus gazella at South Georgia. British Antarctic Survey Bulletin, No. 61, 27-37.

PAYNE, M.R. 1977. Growth of a fur seal population. Philosophical Transactions of the Royal Society London, Series B, 279, 67-79.

RAND, R.W. 1959. The Cape fur seal (Arctocephalus pusill us). Distribution, abundance, and feeding habits off the south westem coast of the Cape Province. South African Division of Sea Fisheries Investigation Report, 34, 1-75.

RichaRDs, R. 1981. The journal of Erasmus Rogers, the first man on Heard Island. American Neptune, 41, 280-305.

RoBerTs, B.B. 1950. Historical notes on Heard and McDonald Islands. Polar Record, 5, 580-584

Roux, J.P. 1987. Recolonization processes in the Subantarctic fur seal, Arctocephalus tropicalis on Amsterdam Island. In Croxall, J.P. \& GENTRY, R.L., eds. Status, biology and ecology of fur seals. NOAA Technical Report. NMFS 51, 189-194.

Shaughnessy, P.D. \& FLetcher, L. 1987. Fur seals, Arctocephalus spp., at Macquarie Island. In CRoxalL, J.P. \& GENTRY, R.L., eds. Status, biology and ecology of fur seals. NOAA Technical Report. NMFS 51, 177-188.

Shaughnessy, P.D., Shaughnessy, G.L. \& Keage, P.L. 1988. Fur seals at Heard Island: recovery from past exploitation? In AugEE, M.L., ed. Marine mammals of Australasia, field biology and captive management. Sydney: Royal Zoological Society of New South Wales, 71-77.

TATE, M.L. 1981. The autumn-winter diet of the New Zealand fur seal Arctocephalus forsteri (Lesson) with special reference to its cephalopod prey. Dipl. Wildlife Management, University of Otago, Dunedin, $52 \mathrm{pp}$. [Unpublished.]

WLliams, R. 1983. The inshore fishes of Heard Island and McDonald Islands, South Indian Ocean. Journal of Fish Biology, 23, 283-292.

Williams, R. \& Ensor P. 1988. Extensive research needed to assess fish resources around Heard Island. Australian Fisheries, 47, 2-4. 